\title{
From Idea to Realisation: The architecture of Jovan Stefanovski
}

\author{
https://doi.org/10.52603/arta.2021.30-1.13
}

\author{
Rezumat \\ De la idee la realizare: Arhitectura lui Jovan Stefanovski
}

Deși nu toată lumea acceptă acest lucru, Republica Macedonia de Nord se poate mândri cu numeroși arhitecți prolifici, implicați adesea în educația în domeniul arhitecturii. Jovan Stefanovski, autorul Crucii Mileniului și al Teatrului Național (ambele în capitala țării Skopje) este un exemplu de astfel de personalitate. Asemănător fostelor generații de arhitecți, stilul său de proiectare amintește din punct de vedere conceptual arhitectura tradițională a țării sale. Cercetând arhiva lui Jovan Stefanovski, a fost identificată o serie de proiecte - eșantion de studii de caz incluse în teza lui de doctorat și discutate în legătură cu tema „ideii” și „realizării” în arhitectură. Conceptul atribuit de el „ideii” este similar „conceptului” utilizat în proiectarea arhitecturală. Dacă ideea este expresia inconștientului, realizarea reprezintă o decizie conștientă de a implementa ideea proiectului.

Stefanovski s-a afirmat ca un arhitect și profesor prolific. Interesul său pentru arhitectura tradițională a corespuns cu tendințele care s-au dezvoltat la sfârșitul anilor 1960 și începutul anilor 1970. Astfel, în concordanță cu abordările arhitecturale dezvoltate de învățătorii lui Stefanovski, idiomul regionalist care a apărut în Macedonia, se manifestă în lucrările lui atât prin formă, cât și prin funcțiune.

Cuvinte-cheie: arhitectură tradițională, casă balcanică, casă macedoneană, modernism, regionalism, regionalism critic, proiectare arhitecturală, Grabrian, Stefanovski, Macedonia de Nord.

\section{Summary \\ From Idea to Realisation: The architecture of Jovan Stefanovski}

Although not widely acknowledged, the Republic of North Macedonia boasts a number of prolific architects who were often engaged in architectural education. Jovan Stefanovski, the author of the Millennium Cross and the National Theatre, both in the capital Skopje, is one such personality. Similar to former generations of architects, his design style conceptually recalls the traditional architecture of his homeland. Researching the Jovan Stefanovski Archive, a number of projects were identified - a sample from the case-studies covered in his doctorate thesis - and discussed with respect to the themes of 'idea' and 'realisation' in architecture. His notion of the former is akin to 'concept' as used in architectural design. While an idea is an expression of the unconscious, realisation is the conscious decision to execute the design idea.

Stefanovski was a prolific architect and educator. His interest in traditional architecture was in line with the trends which developed in the late 1960s and early 1970s. Furthermore, in line with the architectural approaches being developed by Stefanovski's teachers, the regionalist idiom which emerged in Macedonia, is contemporaneously evident in his work both in form and function.

Keywords: traditional architecture, Balkan house, Macedonian house, modernism, regionalism, critical regionalism, architectural design, Grabrijan, Stefanovski, Macedonia.

\section{Introduction}

The title of this article is identical to that of the PhD thesis of Jovan Stefanovski (1948-2019), which was successfully defended at the University of Architecture, Civil Engineering and Geodesy, Sofia, Bulgaria [18]. ${ }^{1}$ The objective of his research, as he stated at the outset, was to define the notion of 'idea' in architecture illustrated through his realised projects, which numbered 400 in total from 1973 to $2002 .^{2}$

Stefanovski, known as Stefanovski-Zan whereby Zan was his nickname which he often made use of in his work, was one of the most prominent contemporary architects of the Republic of North Macedonia [9-11]. He also held various academic posts, which he carried out alongside his architectural work [20]. Following the completion of his architectural education in 1973 at the Faculty of Architecture, Skopje University, now known as Saints Cyril and Methodius University, he finalized his diploma project under the academic supervision of Brutalist architect Georgi Konstantinovski. ${ }^{3}$ As a student, Stefanovski worked for the design office Studioproekt and later at 


\section{Arta contemporană}

Table 1: Characteristics of traditional Macedonian construction in the nineteenth century [18, pp. 11-15]

\begin{tabular}{|c|c|c|}
\hline$n r$. & Characteristics & Typical case-study \\
\hline 1 & $\begin{array}{l}\text { Erection on stepped terrain unfit for agrarian } \\
\text { use but with good air quality and views }\end{array}$ & Panorama of Galičnik from 1928 \\
\hline 2 & $\begin{array}{l}\text { Aesthetic principle of radiality: on limited gro- } \\
\text { und, the upper floors are cantilevered and thus the } \\
\text { building resembles a tree rising to the sun }\end{array}$ & Kanevchevi house, Ohrid \\
\hline 3 & $\begin{array}{l}\text { Main elevation designed to the principles of axi- } \\
\text { ality and symmetry to face the main view }\end{array}$ & Begovski Konak, Debar \\
\hline 4 & Vertical windows & Typical house at Krushevo \\
\hline 5 & $\begin{array}{l}\text { Ground floor erected in stone, whilst upper flo- } \\
\text { ors are in lighter material, such as a timber with brick }\end{array}$ & House of Vasil Glavinov, Veles \\
\hline 6 & Use of colour and ornaments & $\begin{array}{l}\text { Timber ceiling with geometric decorative pat- } \\
\text { tern and polychrome colouring, Stanchevi, Shtip }\end{array}$ \\
\hline 7 & $\begin{array}{l}\text { Large open, closed and covered spaces/verandas } \\
\text { which extends to balconies and glazed bay windows } \\
\text { along most of the elevation }\end{array}$ & Monastery complex 'St Panteleimon', Skopje \\
\hline 8 & $\begin{array}{l}\text { Use of struts - most often timber - for bay win- } \\
\text { dows on floors and verandas }\end{array}$ & Kosta Solev - Racin Memorial House, Veles \\
\hline 9 & $\begin{array}{l}\text { Use of environmentally sound - mainly local - } \\
\text { materials for construction }\end{array}$ & House on Dame Gruev Street, Veles \\
\hline
\end{tabular}

Unikosproekt, both in Skopje. After graduation, he joined the design bureau Granit until, in 1994, he set up his own professional office, Euroarch Studio. He was the former Dean of the Faculty of Architecture at the European Polytechnic University (Pernik, Bulgaria) and the former Dean of the Faculty of Architecture at FON University (Skopje, Macedonia). He was appointed Professor of Architecture at ABB University (Prishtina, Kosovo), MIT University (Skopje, Macedonia) and at the State University of Tetovo (Macedonia). From 2002 until his demise, Stefanovski was a Professor of Architecture on a part-time basis at the University of Architecture, Civil Engineering and Geodesy (Sofia, Bulgaria) [20].

A recurrent theme in Stefanovski's work is idealism. In Europe and along the Mediterranean Basin, this philosophical notion dates back to Classical antiquity. It asserts that 'reality' cannot be distinguished or divorced from human perception. It is a mental constitution related to the realm of ideas. Making reference to some of his projects, the aim of this article is to address how the idea and its realisation were achieved in the architecture of Stefanovski. During the course of this research use was made of the Jovan Stefanovski Archive in Skopje.

\section{The Context}

The heritage legacy of the Republic of North Macedonia dates back millennia. Its sphere of in- fluence over the centuries impacted on various parts of Europe, but most notably on the Balkan Peninsula. Its cultural and built heritage are just recollections of the civilisations which have unfolded through history and come to dominate the territory. The latest empire which controlled the country - for over half a millennium, up to the early twentieth century - was the Ottoman Empire. The vernacular architecture of this era can be read through the traditional 'Balkan house', also known as the 'Ottoman house', a source of inspiration for Stefanovski (Fig. 1). These houses, prevalent in the Balkans, including North Macedonia, and erected by anonymous builders, were functional, spacious and homely properties. Based on scholarly sources, Stefanovski listed nine main characteristics of traditional construction in the nineteenth-century architecture of North Macedonia. ${ }^{4}$ These characteristics, together with a typical case-study to illustrate each, are given in Table 1.

The traditional architecture of Macedonian houses is an ongoing subject of research [e.g., 1, 13, 14, 23-25]. An early influential publication is by Grabrijan, entitled Makedonska kukja (The Macedonian House) [8], first issued in 1955, a few years prior to Tomoski's work [24]. Based on a research trip to study nineteenth-century Macedonian houses in the years just after the end of the Second World War, Grabrijan read them as a resource for 'modern' architectural philosophy: "Their 'human scale, 'plasticity of spaces, 'flexibility', the concept of the 'min- 


\section{Arta contemporană}

imal house', the architectural promenade, the 'unobstructed views', and 'geometry' were the modern principles he discovered in the Macedonian house" [6, p. 307-2]. His study led to the "internationalisation of the Macedonian house" [6, p. 307-2]. He compared his findings to the work of Le Corbusier and noticed the presence of strong similarities. This led him to claim that the design of the Macedonian house might have influenced the architectural language of Modernist architects like Le Corbusier [8]. This theory of architecture significantly influenced post-war architects in Macedonia up to the devastating earthquake of 1963 - the generation of architects prior to Stefanovski, namely his educators at the Faculty of Architecture - who were designing modern/new architecture "based on the concept «become modern» through the "return to sources» $[6$, p. 307-3]". Their architecture style drifted from the idioms associated with the Congrès Internationaux d'Architecture Moderne. In the post-1963 years, traditional architecture became their beacon of inspiration for a new architecture which aimed to reconcile the international and traditional, an approach that in the late 1970s/early 1980s emerged as regionalism [5]. It was indeed a drive towards critical regionalism as understood by Frampton in his 1983 essay 'Towards a Critical Regionalism: Six points for an architecture of resistance' [7]. Frampton's essay draws on phenomenology, a dimension tackled by Norberg-Schulz few years earlier [17].

\section{The architecture of Stefanovski: Case studies}

As an architect in practice, Stefanovski did not fall short from designing residential buildings. Important case studies include (i) the villas in Ohrid (realised 1976), (ii) the villa in Sirhan, Lake Prespa (realised 1977) and (iii) a residential building in Sopishte, Skopje (realised 2001). The site of the villas in Ohrid is picturesque with interconnected terrain overlooking the lake and the historical town of Ohrid [18, pp. 20-21]. As can be seen in Fig. 2, the design was styled after a typical villa, and included elements which recall the memory of the place: the dome (a notable feature in the silhouette of Ohrid), the cylinder (a specific element of Samuel's Fortress in the old town), the significant distinctiveness of the Ohrid architectural vernacular (as exemplified by the Savinov family house, completed in 1827), and the stone ground, a characteristic of the terrain [19].

Although there is no visual contact with the silhouette of the historical core of Prespa region, the villa at Sirhan (Fig. 3) includes various elements which recall tradition: the ground floor is minimal in area, applying the principle of radiality [18, pp. 24-25]. The brick along the elevation and the tiled roof reinforce the vernacular building materials and forms with a typical staircase. There is a veranda on the exterior which extends into the interior, a design inspired by the veranda of the Monastery complex St Panteleimon, Skopje [19].

In the design of the residential building in the village of Sopishte, Skopje (Fig. 4), the elements that connect it with tradition are the free-standing verandas supported by columns through the two floors, and the optimisation of air and light into the dwelling through a row of apertures [18, pp. 76-78]. The interior is a continuation of the verandas; space flows from one to another.

Significant commercial/administrative/hospitality buildings designed by Stefanovski include (i) the Central Branch of the Economic Bank, Probishtip (realised 1986), (ii) the 'House of Craftsmen' located in the old Skopje Bazaar (realised 1990), (iii) the administrative centre of Mashinopromet, Skopje (realised 1990), and (iv) the Spectrum Palace Hotel Complex in Primorsko, Bulgaria (realised 1999). Located in a prominent location of the square, the design of the Central Branch of the Economic Bank broadly follows traditional Macedonian architectural language (Fig. 5) [18, 31-32]. Overlooking the ground level is an open veranda, accessed via flights of stairs which run parallel to the elevation. It has a series of vertical windows and a sloping roof. The design recalls the architecture of the monastery of St Jovan Bigorski [19].

Located in a space which dates to the early Medieval period, the 'House of Craftsmen' (Fig. 6) is inspired by the design of an old house dating back to the nineteenth century. The following elements are integrated into the new design: the typical characteristics of the traditional house were placed on the first floor, which serves as a hall for meetings with a lobby [18, pp. 37-38]. The 'servicing part' is an exhibition space for craftsmen's works. Offices are housed on the ground and first floors.

Stefanovski's interpretation of the urban rectangle occupied by the administrative centre of Mashinopromet is characterized by a main elevation finished in classical grammar, applying symmetry and marked axiality (Fig.7) [18, pp. 28-39]. A row of vertical windows was introduced, recalling the traditional expression illustrated by the houses in Krakovnica, Gorna Reka village [19]. A dome 


\section{Arta contemporană}
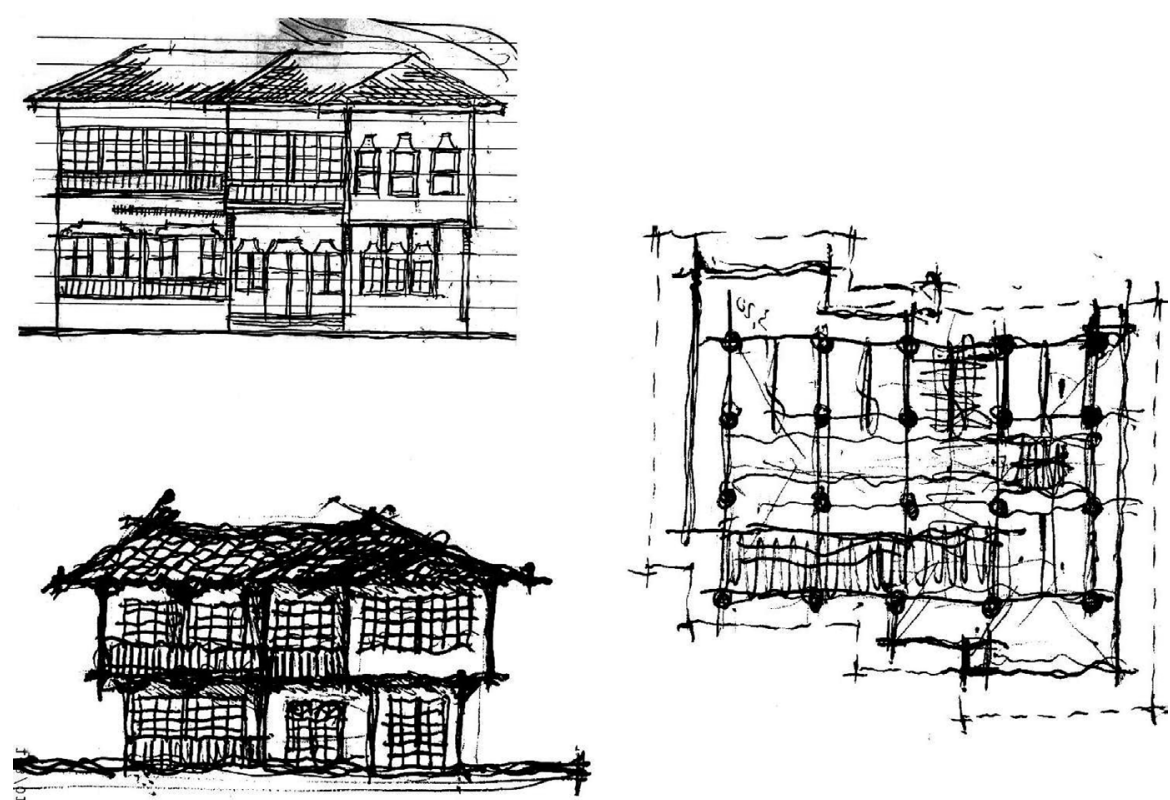

Fig. 1. A study of a traditional Balkan house in Skopje by Stefanovski. (C Jovan Stefanovski Archive.

was introduced to illuminate the lobby; overhanging upper floors suggesting a closed veranda.

The Spectrum Palace Hotel Complex is a complicated development from an ethno-aesthetic aspect (Fig. 8) [18, pp. 59-61]. Located close to archaeological excavations, the environs have significant historical and aesthetic value. Stefanovski's design attempted to interpret various layers to convey a contemporary solution which speaks of the building traditions of Bulgaria and expresses continuity with the architectural and construction principles illustrated by buildings such as the elevation of the Monastery of the Holy Trinity in Etropole and Lamartin House in Plovdiv [19].

The Millennium Cross in Vodno, Skopje (realised in 2002), Stefanovski's opus magnum, respects the strict canons of the Orthodox Church (Fig. 9) [18, pp. 82-84]. Co-designed with his nephew, architect Oliver Petroski, ${ }^{5}$ the size is monumental: the cross is $66(33 \times 2)$ metres plus 14 meters for the platform/base, and spans 24 meters. It is located at a site which has, since antiquity, been known as 'Krstovar', the highest point of the mountain range which surrounds Skopje from the south. ${ }^{6}$ The number 33 symbolizes the earthly life of Christ. The platform is supported by 12 columns - alluding to the 12 apostles - and the cross itself rests on four columns, representing the evangelists.

The National Theatre of Macedonia, Skopje (realised in 2013), a commission won through a public competition, recalls the return of the old baroque memory of the city prior to the earthquake of 1963 , in which $60-70 \%$ of the buildings were destroyed (Fig. 10). Located along the Vardar River, the building - co-designed with Stefanovski's daughter, architect Ivana Stefanovska Cvetkovska ${ }^{7}$ - is not a replica of the former. Whilst the idea was to design a theatre rooted in the 'spirit of the place' - the city's memory - it still had to meet contemporary functional and technological requirements.

\section{Idea - Form - Tradition}

A question which preoccupied Stefanovski was whether the material world preceded ideas or ideas precede the material world. It is interesting that, prior to discussing his notions of idea and realisation, he makes reference to an engraving of the proposal for Mount Athos by the Greek architect and technical adviser to Alexander the Great, Dinocrates of Rhodes (fl. last quarter of the fourth century BC), which he labelled 'Dinocrates and his dream of the city of art and spirituality of Mount Athos' [18, p. 7].

Stefanovski acknowledged that such a question would lead to him being branded as an idealist, despite the fact that he was educated in a school of architecture, whose philosophy was aligned with the German Bauhaus, the quasi-antithesis of idealism. This meta-question can be simplified into more pragmatic language: Does the idea remind one of how a specific task can be resolved, or is it a dictum which stirs an individual to embark on a journey to discover their calling and realise it in their profession which, with time 


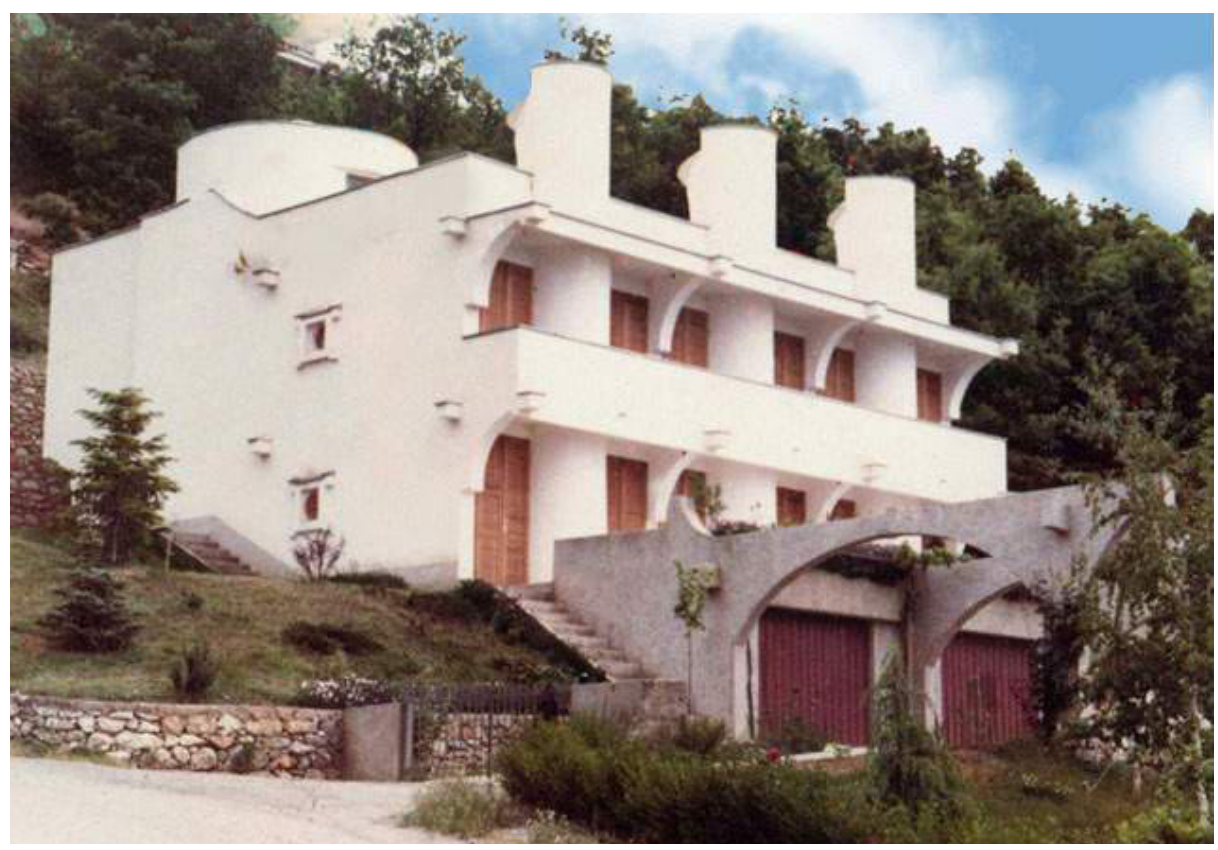

Fig. 2. Villa - one in a series - St Stefan, Ohrid. ( Jovan Stefanovski Archive.

and experience, matures? Is the solution to a given design problem rooted in the idea, or is the idea the awareness that one bears which, as it unfolds, can be realised through one's career and the fruit it bears? For Stefanovski, the latter was the case. His vocational calling to be an architect ensured that the idea could be realised through architecture, namely in the execution of architectural design projects. From this perspective, the idea is the natural genesis of an architect which subsequently develops and, with time, matures into the production of architecture. He was even more convinced that this was the case when the International Academy of Architecture (IAA), recognised by the United Nations Economic and Social Council as a non-governmental organisation with special consultative status, approved the Charter 'HORIZON 2000' at its Fourth Assembly, held in 1994.

The Charter 'HORIZON 2000', which has as its subtitle 'Sustainable architecture for a sustainable world', noted the dynamic emergence of unprecedented developments affecting contemporary society and stated that creative architectural work is in crisis [21, pp. 13-20]. ${ }^{8}$ Noting the importance of meeting the needs of present generations, whilst not compromising the opportunities for future ones, it argued that sustainable development cannot be monofunctional. Sustainable architecture possesses beauty, but one must keep in mind that architecture has both spiritual and material values. The Charter therefore provided direction for the development of contemporary civilization, with architecture seen as both a statement and an activity of civilization. It called for a re-reading of the dictum 'form follows function' (21, pp. 18-19):

"The truth is the application of a whole complex of interwoven principles of sustainable architecture, namely:

$\circ$ form follows the function;

- form follows the materials, construction and technology;

o form follows the context;

- form follows the cultural tradition, social consciousness and lifestyle of society; and ... most importantly,

○ form follows the author's individuality and uniqueness"

To use Boris Chipan's words, Stefanovski was driven by 'sentimental nationalism'. His architectural designs are generally characterised by the following four approaches:

1. borrowing and making use of traditional architecture elements;

2. utilising essential geometric forms and the combination of the same;

3. using analogous traditional construction methods; and

4. applying aesthetic principles through the use of new building materials.

These approaches are not unusual for Macedonian architects raised according to the tenets of Modernism: "The presence of characteristics in traditional houses that were especially praised in Modernism ('architecture of human scale,' 'rela- 


\section{Arta contemporană}

tionship to nature,' etc.) encouraged the modern architects of Yugoslav Macedonia to find inspiration in the vernacular architecture of their native country. Indeed, Macedonian architects in socialist Yugoslav period deliberately placed traditional elements in their projects (storeys in projection in the upper levels, wooden cladding, long eaves, etc.) - in a more literal and imitative way (the Stokovna Kukja Most by Tihomir Arsovski, Skopje, 1977) or as references in a Modernist design (the building of the Macedonian Academy of Sciences and Arts by Boris Chipan, Skopje, 1976)" [13, p. 491]

The realization of the aesthetic form of the 'House of Craftsmen' was undertaken by conveying the connection with the existing built environment. In Stefanovski's own words, the Central Branch of the Economic Bank "fully represent[ed] the process from idea to realisation. The consciousness gave me the opportunity to apply traditional experience in architecture" [19]. In his designs, traditional principles were deliberately introduced and/or interpreted. He did not synthetically apply them; he opted to use them to varying degrees in order to enable him to communicate his desired design statement for a particular project. The design process and its eventual realisation matured with time, craftsmanship being a dimension which one attains through experience.

The Charter 'HORIZON 2000' makes reference to material and spiritual values in architecture. Stefanovski makes reference to the former but not to the latter. In a study undertaken during the 14th World Triennial of Architecture held by the IAA in Sofia in 2015 - which had 'values in architecture' as its theme - practicing architects defined architecture as an art and an applied science, a synergic expression of aesthetics and function which complements the environment [2]. Stefanovski's reference to the spirit of place may be inferred from his borrowing from the vocabulary and grammar of the traditional Macedonian house. Architecture is the existential reality which individuals experience [4]. In his realised projects there is no reference to the metaphysical experience derived from sense experience, an aspect addressed in the architecture of site synthesis [3].

\section{A Freudian interpretation of Plato}

What did the notion of 'idea' constitute for Stefanovski? Being a nationalist and staunch Orthodox Macedonian, his perspective was grounded in the Classical tradition, even when it came to

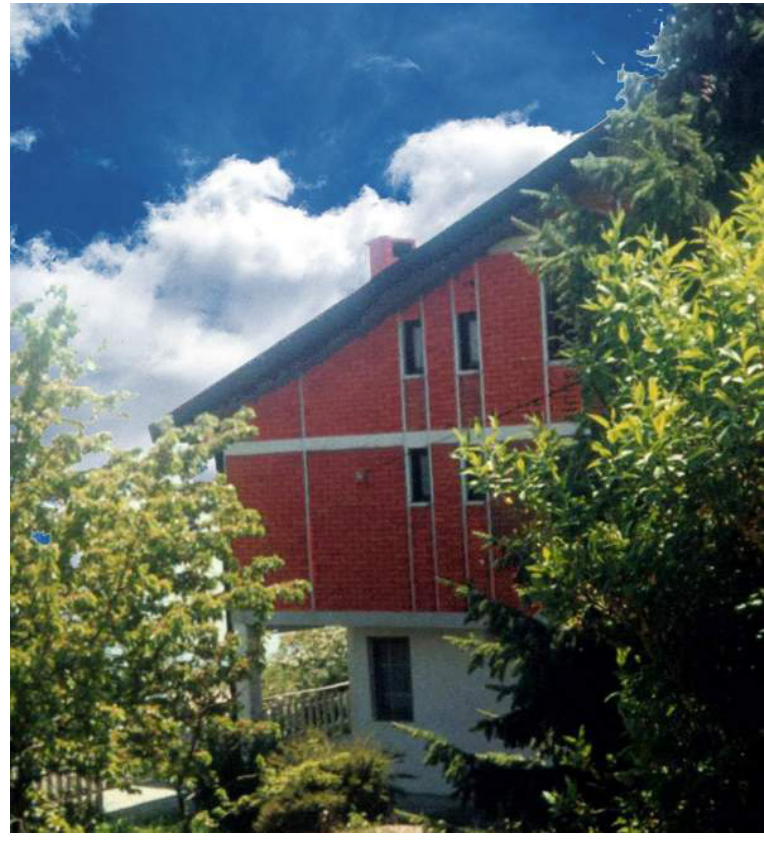

Fig. 3. Villa at Sirhan, Prespa Lake. (c) Jovan Stefanovski Archive.

his philosophy of architecture. Recalling Plato's theory of ideas, he was convinced that only ideas exist. His view was consonant with that of the scholars of ancient Christianity, who asserted that only ideas are eternal and that they precede existence. Yet, he did not remain in the realms of ideas; for him, ideas were eternally real, reality was the manifestation of these ideas. Is the architect a product of a school of architecture, an educational institution which "praise[s] and glorif[ies] only those postulates" who make it through the examination? Or, is the architect born to the profession, as someone in whom "the ideas are embedded ... as a genetic code that penetrates more and more strongly in his work with the accumulation of experience over the years?" [19].

Although seemingly grounded in Plato's theory of forms, Stefanovski's understanding of the notion of idea departed from this Platonic concept; it was more pragmatic and grounded in sense experience rooted in the historical legacy of place. His use of this term is more akin to the notion of 'concept', as used in architectural design. His understanding of an individual discovering his calling to become an architect is more analogous to the unfolding of the Freudian unconscious, in that the architect gradually becomes aware of the art of the profession, as a "true expression of the tradition as a general idea embedded in his own creative capacity" [19]. Stefanovski tried to uncover the unconscious of the suppressed traditional experience in his re- 


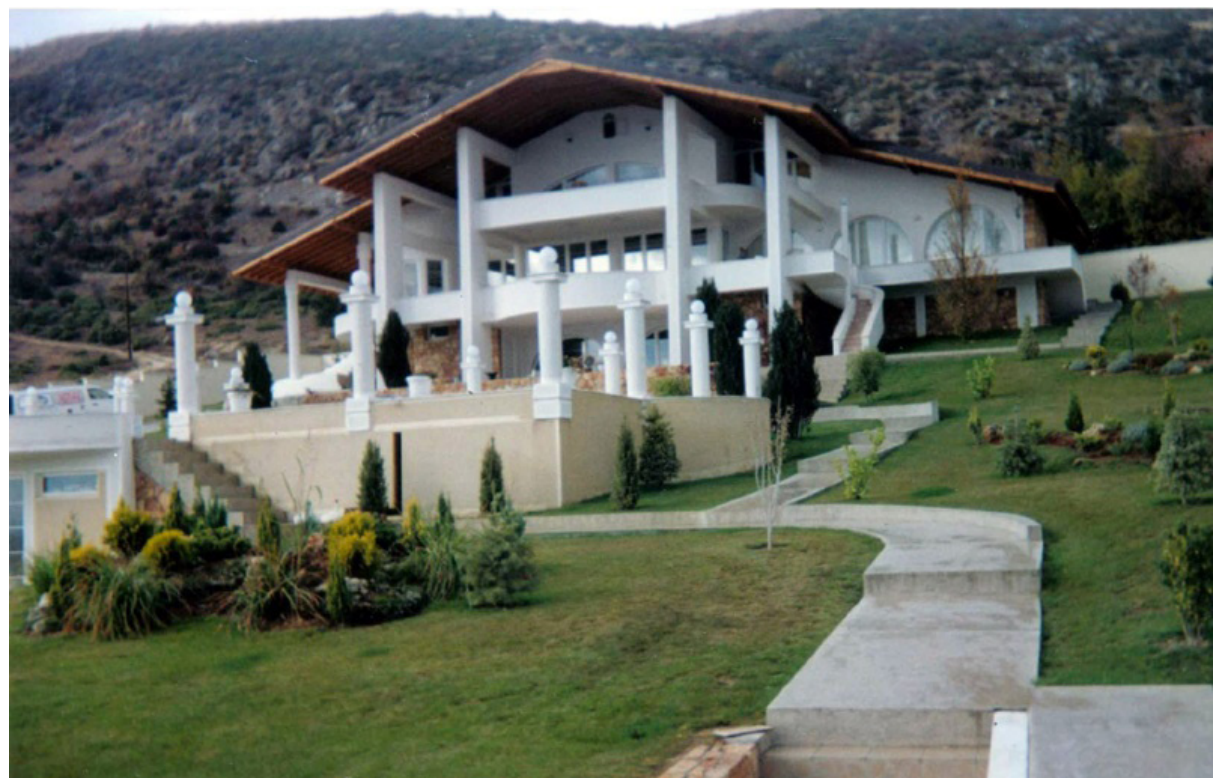

Fig. 4. Individual residential property, P+1, Skopje. (C) Jovan Stefanovski Archive.

alizations [19]. He argued that the formation of an architect inevitably reaches the idea, which predetermines him/her for the profession; s/he "does not create from 'tabula-rasa"' [19]. Realization is an endorsement of the idea, of a cultural context that cannot be diminished or disappear.

Cultural heritage is embedded in the subconscious of the future architect and is the real reason why a student reading architecture is drawn toward this profession. This is the context in which the architect's creativity is realised. An architect gathers resources of information that inevitably lead to the essence of his/her own cultural tradition, "regardless of the recommendations served by the powerful propaganda mechanism and the targeted controlled mechanism of the educational system, particularly [in] influential nations with small populations" [19]. With respect to the education of an architect, however, Stefanovski's argument does not follow from this, and concludes with the following claim [19]:

"The architectural potential of the future architect is shaped by the educational system, it develops, provokes and realises his idea, formed in him by his own climate, culture and society, environment, and complemented by his specific gene".

One can comprehend the claim that culture, society and the environment all form the ground for the philosophy of architectural education, an assertion broadly advocated over the years. The odd dimension in the argument is the importance of the 'gene', that is, of the individual's inner na- ture, in the formation of an architect, as if there is some gene which produces architects. As Albert Einstein pointed out, "genius is 1\% talent and 99\% percent hard work", and it is certainly true that hard work does produce good architects. Stefanovski's claim regarding the significance of gene can be explained through his understanding of the unconscious as a unique personal collective which unfolds in a given individual.

\section{Conclusion}

Stefanovski was a prolific architect and educator. His interest in traditional architecture was in line with the trends which developed in the late 1960s and early 1970s. It was during these years that architects, who taught and practiced Modernism in Macedonia, started drawing inspiration from traditional elements, to "transform' the 'old' house to a modern way of making architecture" [6, p. 307-1]. Furthermore, in line with the architectural approaches being developed by Stefanovski's teachers, the regionalist idiom, which emerged in Macedonia, is contemporaneously evident in his work both in form and function. In both residential and commercial projects, Stefanovski makes use of the liminal space present in the traditional Macedonian house to mark the transition between the inside and the outside, between the unbuilt (nature) and the built (the building) environs.

There are two main areas of impact Stefanovski had on the architecture of his homeland and, to a lesser extent, on architectural education: 

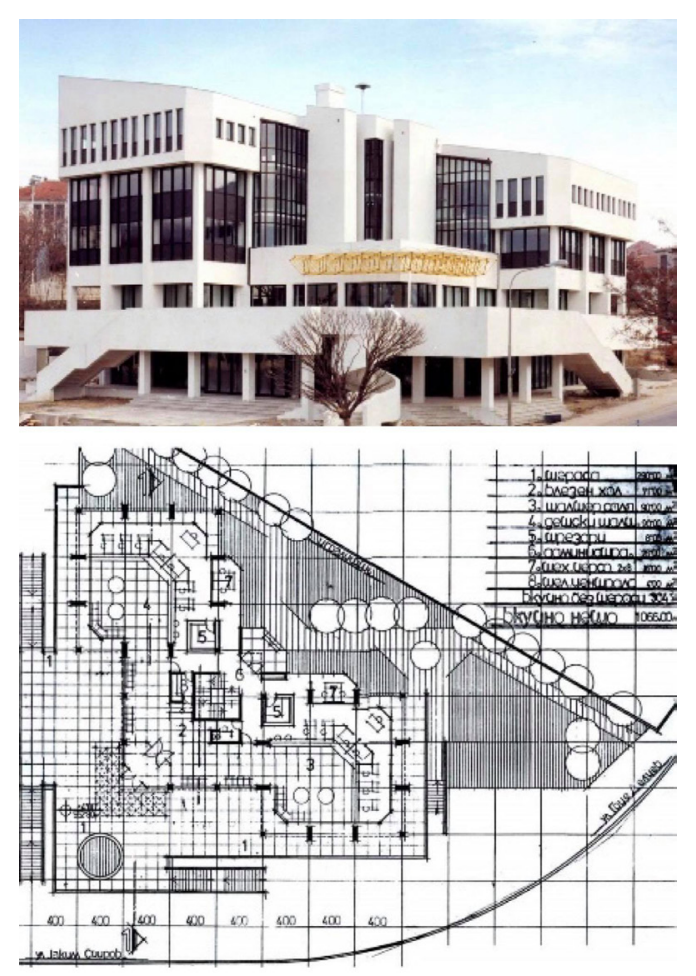

Fig. 5. Central branch of the Economic Bank, Probishtip (top); first floor plan (bottom). (C) Jovan Stefanovski Archive.

1. The numerous realised projects - in particular the Millennium Cross and National Theatre, both in the capital Skopje - are part of his legacy to the built heritage. These two national monuments serve, respectively, as statements of the spiritual and cultural identity of the Republic of North Macedonia.

2. During his long years of teaching, he helped in the formation of generations of architects. His theory of architecture is an interesting, albeit undeveloped, area of research which needs to be investigated and interpreted in the wider context of the literature on architecture.

\section{Author's Note}

This paper is dedicated to Professor Dr Arch. Jovan Stefanovski, a colleague at the Faculty of Architecture, University of Architecture, Civil Engineering and Geodesy (UACEG), Sofia. His way of reading architecture and his enthusiasm to support colleagues, students, and others was truly impressive. My gratitude also goes to Prof. Dr Arch. Yordan Radev, who introduced me to Stefanovski in 2005 when I first arrived at UACEG.

\section{Acknowledgment}

The author would like to express his gratitude to Gordana Stefanovska, the spouse of Stefano-
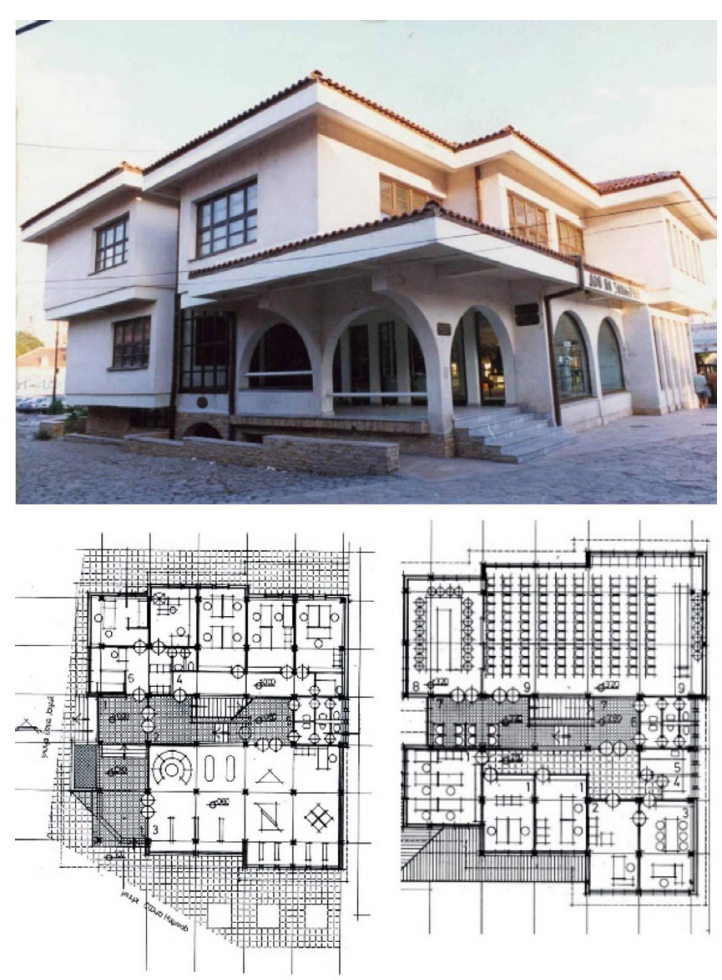

Fig. 6. 'House of Craftsmen', Skopje 9 (top); ground (bottom, left) and first (bottom, right) floor plan. (C) Jovan Stefanovski Archive.

vski, for granting access to the Jovan Stefanovski Archive and permission to reproduce some of its photos and drawings in this publication, and to Stefanovski's children: Ivana, an architect and later partner at her father's bureau, Zhana and Ljubica. Thanks are also due to Borche Veljanovski for helping me with the translations from the Macedonian language.

\section{Notes}

${ }^{i}$ Indeed, it was also the theme of a lecture which Stefanovski delivered to students on the history and theory of architecture courses at the Department of Architecture and Urban Design, Faculty for the Built Environment, University of Malta, in May 2017. Due to his limited use of English, he was assisted by his daughter Dr Eng. Arch. Ivana Stefanovska Cvetkovska. This lecture is available at the Jovan Stefanovski Archive in Skopje, Republic of North Macedonia.

${ }^{\text {ii }}$ Over the course of his professional career, he engaged in over 520 projects, ranging from street furniture to national monuments, as well as numerous buildings, interiors, scenography and urban designs. [20]. He participated in 19 anonymous competitions and ranked first in nine of them. His most notable designs are the Millennium Cross and the National Theatre (which are discussed later in the article), both in Skopje.

iii After completion of his studies in Skopje, Konstantinovski (1930-2020) undertook postgraduate studies at Yale Department of Architecture when it was 


\section{Arta contemporană}

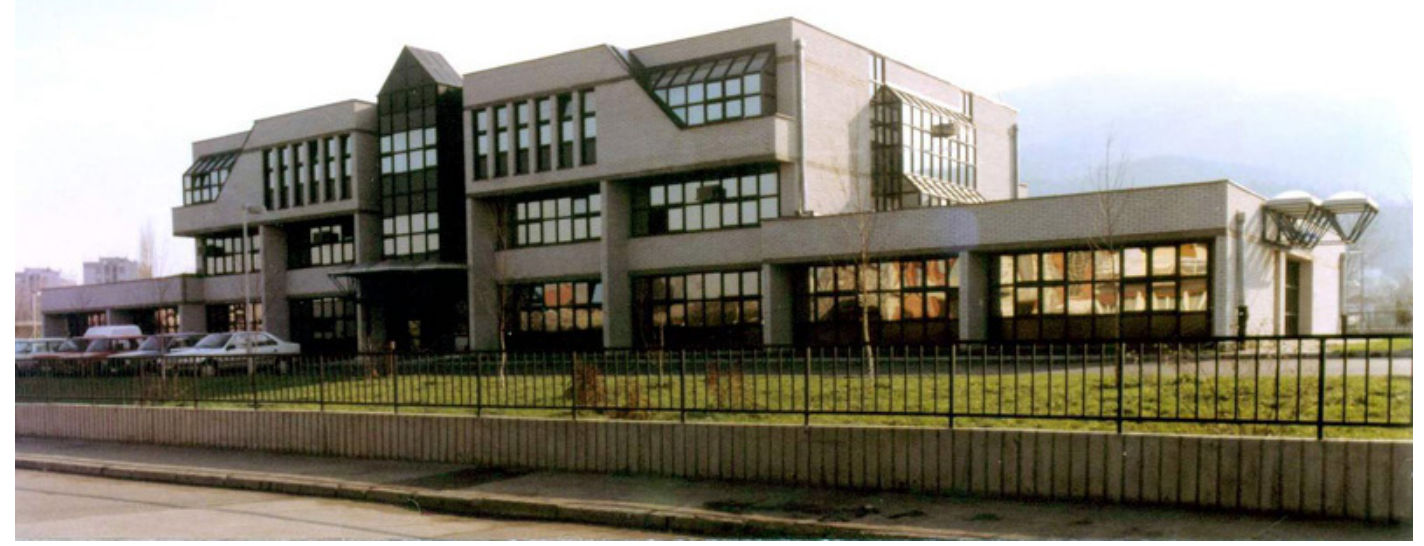

Fig. 7. Administrative centre of Mashinopromet, Skopje. (C) Jovan Stefanovski Archive.

under the direction of Paul Rudolph (1918-1997) and the Jewish Russian-born British architect Serge Chermayeff (1900-1996). The former led the department from 1958 to 1962 and the latter from 1962 to 1971. Konstantinovski worked within the New York office of Ieoh Ming Pei (1917-2019). He designed over 450 architectural and urban projects; notable ones include the City Archive (1968, Skopje), the Student Dormitories of Goce Delcev (1969, Skopje), the Memorial House of the Razlovci Uprising (1981, Razlovci), and ASNOM Memorial Centre (2004, Pelince) [12].

iv Stefanovski listed the architects Krum Tomovski (1924-2010), Boris Chipan (1918-2012), Sotir Tomoski (1899-1985), Mihail Tokarev (?-?), Jasmina Hadzhieva
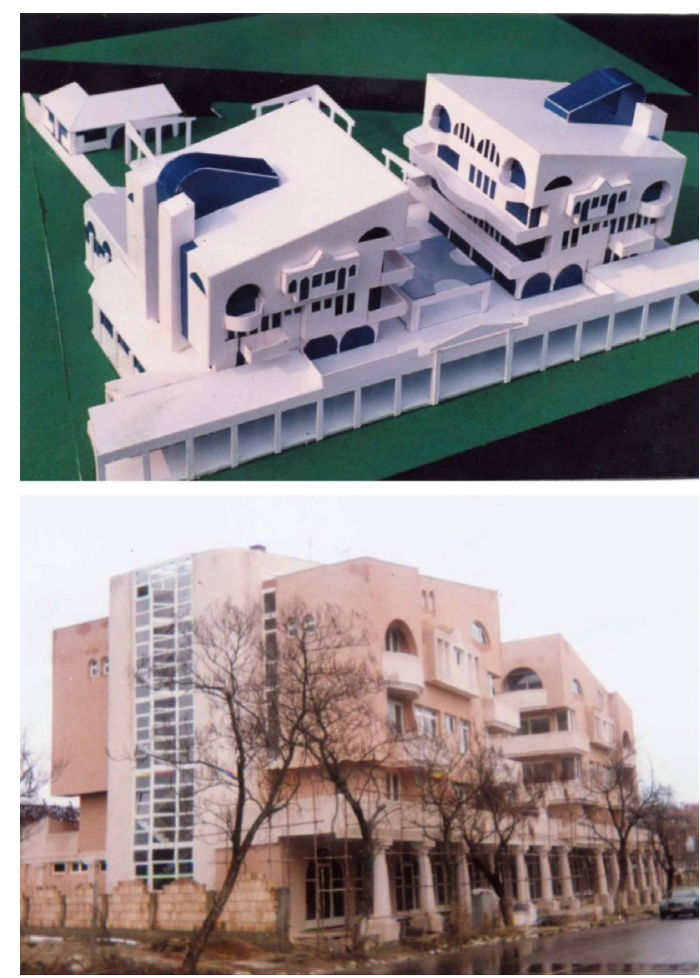

Fig. 8. Spectrum Palace Hotel Complex, Primorsko, Bulgaria: (top) model, (bottom) as built. (C) Jovan Stefanovski Archive.
Aleskievska (?-?), Dushan Grabrijan (1899-1952), and Mirche Kokalevski (1952) [18, p. 11] but did not make reference to any of their works, whether design projects or publications. In the academic and professional literature, the term 'traditional architecture' in Macedonia refers to the period spanning from the nineteenth to the first half of the twentieth century, a period marked by a construction boom [15].

${ }^{v}$ Petroski (1970-), one of the most promising architects of the Republic of North Macedonia, set up his architectural design and engineering studio, Arhi Grup Plan A, in 2000, after being engaged with Stefanovski's office since 1994. He completed his architectural education at Saints Cyril and Methodius University, Skopje, and his $\mathrm{PhD}$ at the University of Architecture, Civil Engineering and Geodesy, Sofia. He is currently Professor of Architecture at AAB University, Prishtina, Republic of Kosovo.

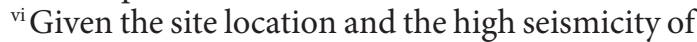
the region, it was deemed imperative that the structure of the Millennium Cross should meet a high level of static and dynamic stability. For this reason, thorough geophysical investigations were undertaken. Furthermore, noting the altitude at which the structure was going to be erected - exposing it to severe wind -analyses were undertaken to obtain insight into the dynamic response of the construction to the effect of earthquakes of varying magnitude together with varying wind loadings [22].

vii Stefanovska Cvetkovska (1979-) completed her architectural education at Saints Cyril and Methodius University, Skopje, and continued her studies at the University of Architecture, Civil Engineering and Geodesy, Sofia, from where she graduated with a MArch and later a PhD. She worked with her father at Euroarch Studio, Skopje, from 2001 until his demise in 2019. She designed over 150 projects, a number of which have been realised.

viii The date of the publication is not included. Given that it includes the Charter 'Horizon 2000', it was either published in the last half of 2004 or in 2005 . The latter date is more likely. The publishing house of the International Academy of Architecture was closed in 


\section{Arta contemporană}
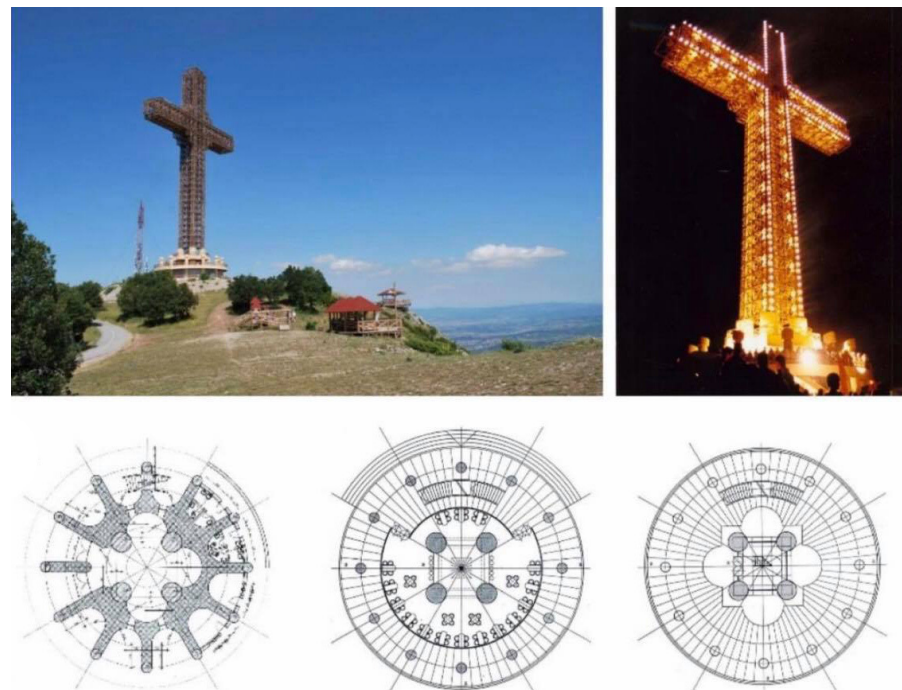

Chapel (level -3.00 m) Restaurant (level $0.00 \mathrm{~m}) \quad$ Terrace (level $+4.00 \mathrm{~m}$ )

Fig. 9. The Millennium Cross: (top) as at present; (bottom) plan at various levels. (c) Jovan Stefanovski Archive.

2006 (Dr Arch. Marina Aleksandrova Vasileva, personal communication, 13.02.2021). The Charter was signed by the Chair, Georgi Stoilov, and several academicians including Justus Dahinden (Switzerland), Vakhtang Davitaia (Georgia), Kisho Kurokawa (Japan), César Pelli (Argentine-American), Jørn Utzon (Denmark), and the leading architect and scholar on the history and theory of architecture Bruno Zevi (Italy).

\section{Bibliography}

1. Atkovska, Irena, Murata Roy. The in-between space: Lessons from vernacular architecture in North Macedonia. IOP Conference Series: Earth and Environmental Science, 2020, v. 588, no. 1.06 - 1.10, 032087.: https://iopscience.iop.org/article/10.1088/1755-1315/588/3/032087/pdf

2. Bianco, Lino. Defining architecture: a qualitative research. Annual of the University of Architecture, Civil Engineering and Geodesy. Sofia, 2018, v. 51, no. 1, pp. 59-66.: https://www.um.edu.mt/library/oar/ handle/123456789/34084

3. Bianco, Lino. Beyond Geodesign: The architecture of sitesynthesis. Journal of Applied Engineering Sciences, 2017, v. 7, no. 2, pp. 17-24.: DOI: https://doi. org/10.1515/jaes-2017-0008

4. Bianco, Lino. Architecture, Values and Perception: Between rhetoric and reality. Frontiers of Architectural Research, 2018, v. 7, no. 1, pp. 92-99.: https:// doi.org/10.1016/j.foar.2017.11.003

5. Chipan, Boris. Texts on architecture. Skopje: 1998. (In Macedonian).

6. Elezi, Kujtim, Saliu, Nuran. Toward a Local Tradition: Modern Architecture in Macedonia. Proceedings of the 2nd ICAUD International Conference in Architecture and Urban Design, Epoka University, Tirana, Albania, 08-10 May 2014. Paper No. 307.: http:// dspace.epoka.edu.al/bitstream/handle/1/1047/307. pdf? sequence $=1$ (visited 14.02.2021).
7. Frampton, Kenneth. Towards a Critical Regionalism: Six Points for an Architecture of Resistance. In: The Anti-Aesthetic: Essays on Postmodern Culture. Ed. Hal Foster. Port Townsend, Washington: Bay Press, 1983. pp. 16-31.

8. Grabrijan, Dushan. The Macedonian house: or its transition from old oriental to modern European house. Skopje: Misla, 1986. (In Macedonian).
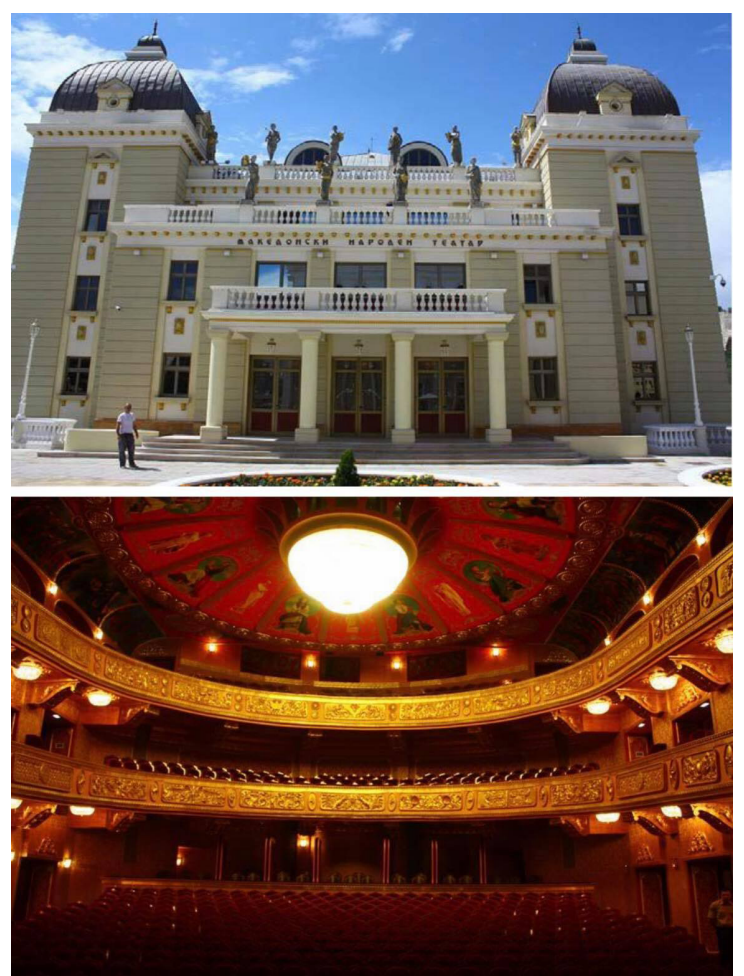

Fig. 10. National Theatre of Macedonia: (top) main entrance, (bottom): interior. (c) Jovan Stefanovski Archive. 
9. In Memory of Jovan Stefanovski-Zan (19482019): Author with fruitful architectural work. Porta3 01/08/2019. Available in: https://www.porta3.mk/inmemoriam-jovan-stefanovski-zhan-1948-2019-avtorso-plodno-arhitektonsko-tvoreshtvo/?fbclid=IwAR3y gcC26o8RNo5MnZXfWUw9KCrB5usy7kVd5fAvAxRJc1WLtpIy09MDUhE (visited 11.02.2021)..

10. Jovan Stefanovski died - The architect who is the author of the Millennium Cross. Free Press. 12.06.2019. Available in: https://www.slobodenpecat. mk/en/pochina-jovan-stefanovski-arhitektot-koj-eavtor-na-mileniumskiot-krst/ (visited 14.02.2021).

11. Jovan Stefanovski - Zan, one of the leading Macedonian architects, has died. Republika. 12.06.2019. Available in: https://english.republika. $\mathrm{mk} / \mathrm{news} / \mathrm{macedonia/jovan-stefanovski-zan-one-of-}$ the-leading-macedonian-architects-has-died/ (visited 14.02.2021).

12. Lozanovska, Mirjana. (2015) Brutalism, Metabolism and its American Parallel. Fabrications, 2015, v. 25 no. 2, pp. 152-175.: DOI: 10.1080/10331867.2015.1032482

13. Marinov, Tchavdar. "The 'Balkan House': Interpretations and Symbolic Appropriations of the Ottoman-Era Vernacular Architecture in the Balkans". In Roumen Daskalov, Tchavdar Marinov, Diana Mishkova, and Alexander Vezenkov (eds.), Entangled Histories of the Balkans. Vol. 4: Concepts, Approaches, and (Self-) Representations. Brill: Leiden \& Boston, 2017. pp. 440-593.: DOI: https://doi. org/10.1163/9789004337824_008

14. Mulichkovski, Petar. The creative spirit of the Macedonian House. Skopje: AEA Publishing, 2000. (In Macedonian).

15. Namicev, Petar, and Namiceva, Ekaterina. Traditional Architecture with Contemporary Use. Methods of Preserving the National Architecture of Macedonia. Journal of Settlements and Spatial Plan- ning, 2016, v. 7, no. 1, pp. 89-97.: http://dx.medra. org/10.19188/09JSSP012016

16. Nikoloska, Marina. City houses of the 19th century in Macedonia, spatial structure. Skopje: Faculty of Architecture, 2007. (In Macedonian).

17. Norberg-Schulz, Christian. Genius loci: Towards a phenomenology of architecture. New York: Rizzoli, 1980.

18. Stefanovski, Jovan. From idea to realization. Unpublished $\mathrm{PhD}$ thesis. University of Architecture, Civil Engineering and Geodesy. Sofia. 2002, 180 p. (In Bulgarian).

19. Stefanovski, Jovan. From idea to realization. Lecture delivered at the University of Malta, April 2017. Unpublished. Jovan Stefanovski Archive.

20. Stefanovski, EU_CV_JovanStefanovski_2017, 2017. Unpublished. Jovan Stefanovski Archive.

21. Stoilov, Georgi. (ed.). International Academy of Architecture. Sofia, 2005.

22. Talaganov, Kosta, Garevski, Mihail, Ristic, Danilo, and Micov, Vlado. Comparative dynamic stability study of a high-rise structure exposed to seismic and wide effects - case study. 13th World Conference on Earthquake Engineering, Vancouver, British Columbia, Canada, August 1-6, 2004. Paper no. 778. Available in: http://www.iitk.ac.in/nicee/wcee/article/13_778.pdf (visited 14.02.2021).

23. Tokarev, Mihail. 100 years of Modern Architecture 3. Skopje: DataPons, 2006. (In Macedonian).

24. Tomoski, Sotir. Macedonian vernacular architecture. Skopje: Faculty of Architecture, 1960. (In Macedonian).

25. Tomovski Krum, Volinjec Radomir, Tokarev Mihail, and Hadzhieva Aleskievska Jasmina. Kratovo - Old architectural and urbanistic contents. Skopje: Macedonian Academy of Sciences and Arts, 1980. (In Macedonian). 